\title{
APPLICATION OF KNOWLEDGE BASED SYSTEMS IN TECHNICAL PREPARATION OF MACHINE PARTS PRODUCTION
}

\author{
Izabela Kutschenreiter-Praszkiewicz
}

\begin{abstract}
S u m m a r y
The paper presents problems of technical product preparation tasks aimed at product selection and redesign for particular application supported by AI methods. The identification of customer needs was discussed, as well as the issues of product decomposition were presented. The QFD method was suggested to be applied as the product and process data integration tool, where the engineering characteristic of a product was combined with its trade characteristic. In the industrial product characteristic, the delivery time, which can be fixed with the use of graph based scheduling method, is particularly important. The paper shows that thanks to the application of KBS methods in production preparation it is possible to support decision making connected with product selection for particular use.
\end{abstract}

Keywords: technical preparation, knowledge based systems, configuration

\section{Systemy bazujące na wiedzy w technicznym przygotowaniu produkcji wyrobów}

$$
\text { Streszczenie }
$$

W pracy przedstawiono analizę zadań technicznego przygotowania produkcji (TPP) ukierunkowanych na dobór i adaptację wyrobu do danego zastosowania wspomaganą metodami AI. Analizie poddano zagadnienia identyfikacji potrzeb klienta. Omówiono zagadnienia dekompozycji wyrobu. Zastosowano metodę QFD jako narzędzia integracji danych z zakresu TPP. Charakterystykę techniczną wyrobu powiązano z charakterystyką handlową obejmująca m.in. termin realizacji. Wykazano, że zastosowanie metod KBS w przygotowaniu produkcji umożliwia wspomaganie decyzji w zakresie doboru wyrobu do danego zastosowania.

Słowa kluczowe: techniczne przygotowanie produkcji, systemy bazujące na wiedzy, konfiguracja

\section{Aims of product technical preparation in knowledge based systems}

Product configuration needs functional and physical analysis of product features. PN-ISO 10007:2005 - "Guidelines for configuration management" gives directions related to the product configuration process in an enterprise and

\footnotetext{
Address: Izabela KUTSCHENREITER-PRASZKIEWICZ, Ph.D. Eng.: University of Bielsko-Biała, Department of Industrial Engineering, 43-309 Bielsko-Biała, Willowa 2, Poland, phone: (0-48, 33) 8279 282, e-mail: ipraszkiewicz@ath.bielsko.pl
} 
indicates the meaning of compatibility between customer requirements related to functional and physical product features of the offered product.

The aim of product technical preparation is to create product offer which is suitable for a particular client and fulfil all his requirements. Product redesign causes risk, which should be taken into consideration in the product configuration process.

In a redesign product configuration it is indispensable to develope knowledge systems related to possible changes in product structure and the production process. In make-to-order product it is important to take into consideration functional and physical characteristics, as well as trade characteristics including delivery time, price and warranty.

Therefore, the knowledge system proposed by [1] can help in identifying of potential manufacturing problems early in design stage and in determining of machining precedence constraints (hard constraints) in situation of feature volumetric interaction, [2] presents the logic level of the object database oriented on manufacturing features.

There is a gap in methodology of configuring make-to-order products, which needs to be redesigned.

Knowledge based systems could be useful as a tool for finding the most suitable product for particular client and assessing product characteristics needed in offer preparation.

\section{Algorithm of data estimation regarding to redesign product}

\subsection{Assumptions of the algorithm}

Tasks related to data estimation regarding to redesign product in the proposed approach include, among others: finding the most suitable product components for the particular client, product variants evaluation, assessment of the adapted product characteristic.

The proposed algorithm of data estimation regarding to redesign product (Fig. 1) is based on the following assumptions: structure,

- the product could be divided into components or units with modular

- there exist some alternatives of components and/or product units,

- enterprise staff is experienced in product adaptation according to individual customer requirements,

- the enterprise is experienced in a small lot production,

- the analysis of product and process risk is made in the enterprise.

Application of AI methods for product configuration according to the proposed algorithm of data estimation needs proper knowledge of representation 
methods. In the presented approach, the chosen methods of knowledge representation were used:

- procedural knowledge representation, applied for: identification of product features recognized by the customer, identification of product features recognized by the producer,

- declarative knowledge representation, used for: definition of the correlation between product features recognized by the customer and the producer, definition of the evaluation rules,

- artificial neural network ANN knowledge representation, used for: assessing of missing manufacturing process parameters,

- case based reasoning CBR knowledge representation, used for: product alternatives identification.

Identification of product characteristics from the customer and producer points of view

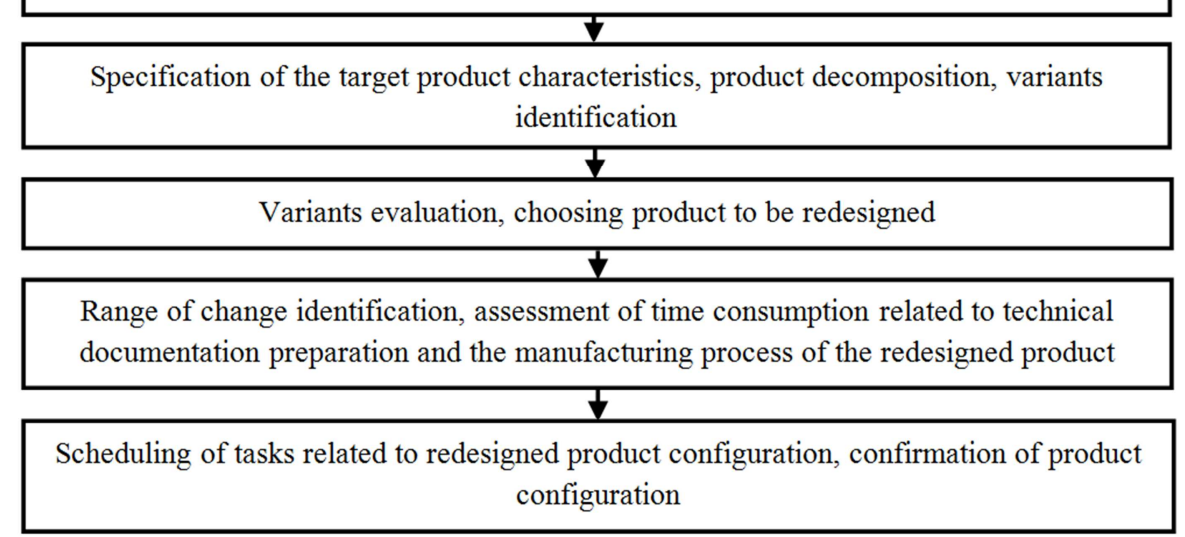

Fig. 1. Algorithm of data estimation regarding to redesign product

\subsection{Identification of product characteristic from the customer and producer points of view}

Identification of product characteristics from the customer point of view could be made in three stages.

The first stage regarding category of requirements, and it is related to product functions, which could include e.g.: torque transmission, weight of material handling, velocity of material handling.

The second stage regarding category of requirements includes product environment conditions, like e.g.: environment temperature; dustiness; humidity; explosive environment. 
The third stage regarding category of requirements includes product trade characteristics, for instance: price; delivery time; warranty.

On the other hand, identification of product characteristics from the producer point of view includes engineering characteristic and trade characteristics. Product characteristics could be identified with the use of a coding system.

\subsection{Specification of target product characteristics, product decomposition, variants identification}

The first stage is focused on defining the functions which transform customer product characteristics into the engineering characteristic. The functions come from theoretical or empirical study of physical and economical dependency.

The second stage specifies the target product characteristics based on functions defined in the previous step. Target values of engineering characteristics should be entered to the bottom row in the QFD matrix. The example of target values setting for feeding device was shown on the Fig. 2.

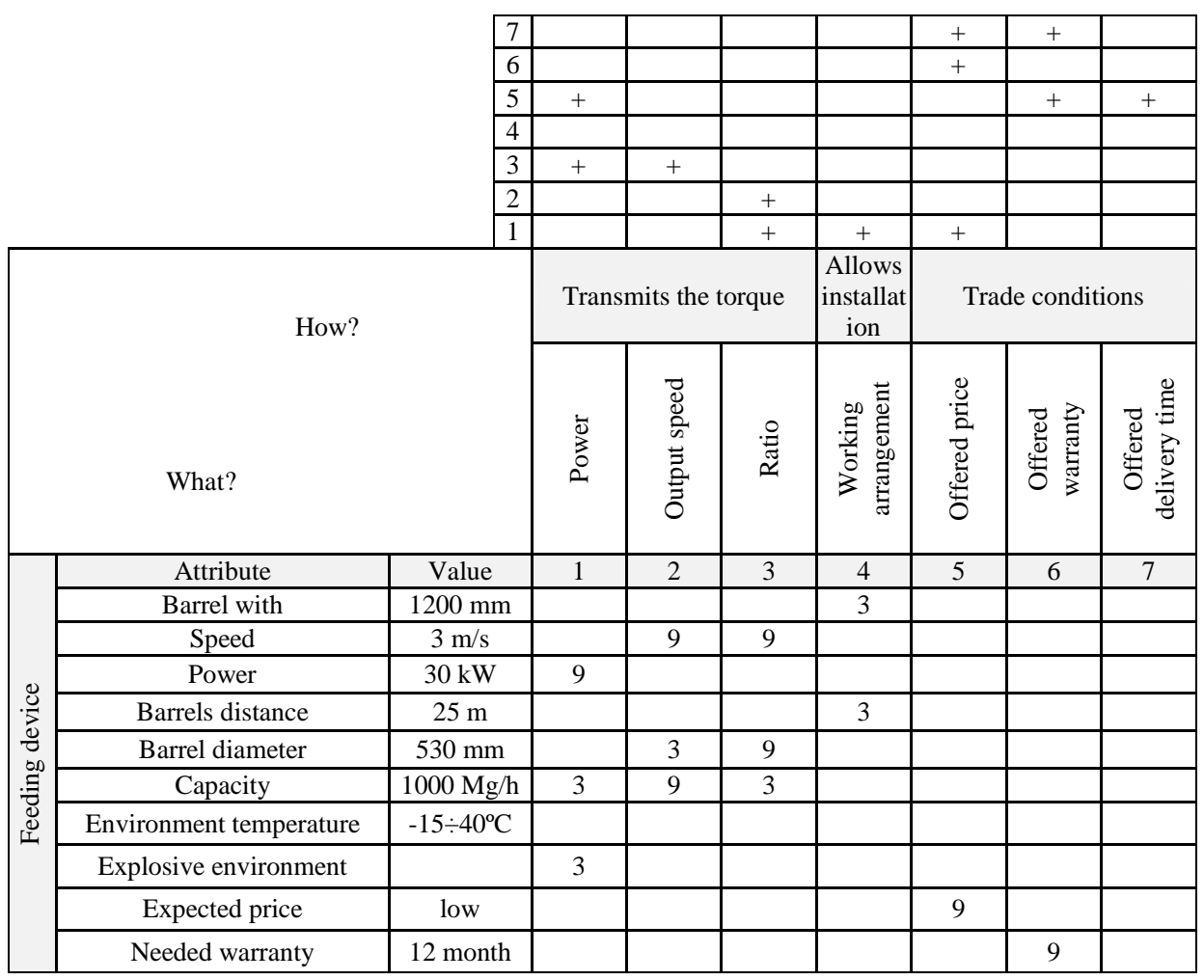




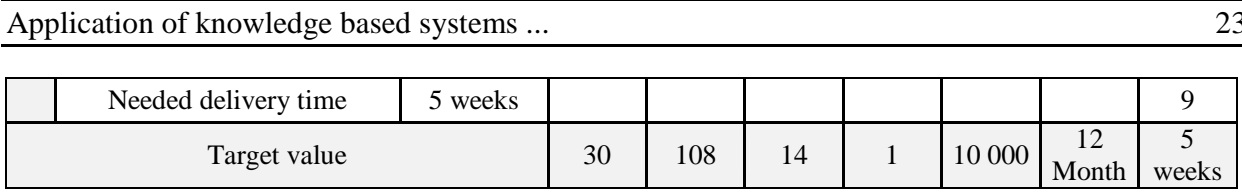

Fig. 2. Product target value identification

The third stage is concerned with identifying the product structure, product decomposition and selecting the configuration item. According to [3] configuration item means: an entity within configuration that satisfies an end use function. A too detailed product decomposition causes costs, but rough product decomposition causes risk related to product characteristics failure.

Product characteristics made from the customer point of view should be related to product characteristic which comes from product structures and the manufacturing process. Product development needs a proper data structure, which helps to join the data vital for customer satisfaction.

The QFD method helps in comparing the needed and the offered product characteristics. If the identified of configuration item does not fulfil the requirements, it should be redesigned. A characteristic of the feeding device configuration item was shown in the Table 1.

Table 1. Feeding device configuration items

\begin{tabular}{|c|c|c|c|c|c|c|c|}
\hline \multirow{3}{*}{$\begin{array}{c}\text { Configuration } \\
\text { item }\end{array}$} & \multirow{2}{*}{ Alternatives } & \multicolumn{6}{|c|}{ Attributes } \\
\cline { 3 - 8 } & & $\begin{array}{c}\text { Power, } \\
\text { kW }\end{array}$ & $\begin{array}{c}\text { Speed, } \\
\text { r.p.m. }\end{array}$ & Ratio & $\begin{array}{c}\text { Delivery } \\
\text { time, } \\
\text { days }\end{array}$ & $\begin{array}{c}\text { Costs, } \\
\text { zt }\end{array}$ & $\begin{array}{c}\text { Warranty, } \\
\text { month }\end{array}$ \\
\hline \multirow{3}{*}{ Toothed gear } & $\mathrm{t} 1$ & 33 & 83 & 18 & 30 & 5000 & 12 \\
\cline { 2 - 8 } & $\mathrm{t} 2$ & 49 & 83 & 18 & 32 & 5200 & 12 \\
\cline { 2 - 8 } & $\mathrm{t} 3$ & 24,5 & 83 & 18 & 29 & 4800 & 12 \\
\hline \multirow{3}{*}{ Motor } & $\mathrm{t} 4$ & 30 & 1470 & & 10 & 3200 & 3 \\
\cline { 2 - 8 } & $\mathrm{t} 5$ & 35 & 1770 & & 15 & 3100 & 12 \\
\cline { 2 - 8 } & $\mathrm{t} 6$ & 30 & 1470 & & 15 & 3300 & 12 \\
\hline \multirow{3}{*}{ Brake } & $\mathrm{t} 7$ & & & & 20 & 100 & 12 \\
\cline { 2 - 8 } & $\mathrm{t} 8$ & & & & 30 & 90 & 6 \\
\cline { 2 - 8 } & $\mathrm{t} 9$ & & & & 10 & 110 & 24 \\
\cline { 2 - 8 } & $\mathrm{t} 10$ & & & & 10 & 20 & 12 \\
\cline { 2 - 8 } & $\mathrm{t} 11$ & & & & 12 & 40 & 12 \\
\hline
\end{tabular}

\subsection{Variants evaluation, choosing the product to be redesigned}

The next step of product configuration is evaluating the variants of product components. The proposed procedure of product evaluation is focused on fulfilling customer satisfaction. 
The proposed approach joins well known optimisation method with the rule-based approach. The proposed approach bases on calculation of the variation coefficient for each evaluated attribute and variant $w_{k z t}$ according to equation:

$$
w_{k z t}=\frac{\left|p_{m k z t}^{w o z}-p_{m k z t}^{w}\right|}{p_{m k z t}^{w o z}} \cdot 100
$$

where: $w_{k z t}$ - variation coefficient calculated for component $k$, attribute $z$, variant $t, p_{m k z t}{ }^{w o z}$ - perfect attribute value, $p_{m k z t}{ }^{w}$ - real attribute value.

In the proposed approach grade determination for each configuration item variant is determined with the use of $w_{k z t}$ coefficient and rules described the degree of requirements fulfilment. The rules of grade determination enable to analyse each attribute separately. Overall evaluation is possible according to equation:

$$
s_{k t}=\frac{\sum_{z} s_{k z t} \cdot k_{z}}{\sum_{z} k_{z}}
$$

where: $s_{k t}$ - average grade for variant $t$, component $k, k_{z}$-importance of grade for attribute $z, k_{z} \in N ; s_{k t} \in\{1,2,3,4,5\} ; s_{k z t}$ - grade for variant $t$, component $k$, attribute $z$.

The example of $w_{k z t}$ coefficient calculation and $\mathrm{s}_{k z t}$ grade determination for configuration items of feeding device was presented in the Table 2.

\begin{tabular}{|c|c|c|c|c|c|c|c|c|c|c|c|c|c|}
\hline \multirow{2}{*}{ ن } & \multirow{2}{*}{ 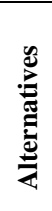 } & \multicolumn{12}{|c|}{ Attributes } \\
\hline & & $w_{k 1}$ & $s_{k I}$ & $w_{k 2}$ & $s_{k 2}$ & $w_{k 3}$ & $s_{k 3}$ & $w_{k 4}$ & $s_{k 4}$ & $w_{k 5}$ & $s_{k 5}$ & $w_{k 6}$ & $s_{k \sigma}$ \\
\hline \multirow{3}{*}{$\begin{array}{l}\text { Toothe } \\
\text { d gear }\end{array}$} & $\mathrm{t} 1$ & 0,1 & 5 & 7,3 & 1 & 0,3 & 4 & 0,6 & 4 & 0 & 4 & 0 & 5 \\
\hline & t2 & 0,6 & 4 & 7,3 & 1 & 0,3 & 4 & 0,6 & 4 & 0,04 & 4 & 0 & 5 \\
\hline & t3 & 0,2 & 4 & 7,3 & 1 & 0,3 & 4 & 0,6 & 5 & 0,04 & 4 & 0 & 5 \\
\hline \multirow{3}{*}{ Motor } & t4 & 0,00 & 5 & & & & & 6,67 & 3 & 66,67 & 1 & 75,00 & 1 \\
\hline & t5 & 16,67 & 1 & & & & & 3,33 & 4 & 50,00 & 1 & 0,00 & 5 \\
\hline & t6 & 0,00 & 5 & & & & & 10,00 & 3 & 50,00 & 1 & 0,00 & 5 \\
\hline \multirow{3}{*}{ Brake } & $\mathrm{t} 7$ & 33,33 & 1 & & & & & 86,67 & 1 & 33,33 & 1 & 0,00 & 5 \\
\hline & t8 & 0,00 & 5 & & & & & 88,00 & 1 & 0,00 & 5 & 50,00 & 1 \\
\hline & t9 & 16,67 & 1 & & & & & 85,33 & 1 & 66,67 & 1 & 100,00 & 1 \\
\hline
\end{tabular}

Table 2. Feeding device configuration items - determination of $w_{k z t}$ coefficient and $s_{k z t}$ grade 


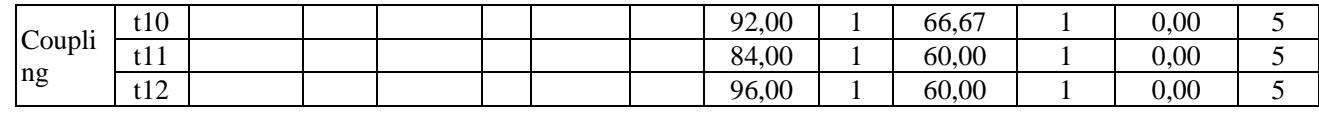

The presented approach helps to identify the importance of product attribute and compare product components (Fig. 3).

\begin{tabular}{|c|c|c|c|c|c|}
\hline \multicolumn{2}{|c|}{ What? } & Toothed gear & Motor & Brake & Coupling \\
\hline Attribute & Value & 1 & 2 & 3 & 4 \\
\hline Power & $30[\mathrm{~kW}]$ & 9 & 3 & 3 & \\
\hline Output rotational speed & 108 [r.p.m.] & 9 & & & \\
\hline Ratio & 14 & 9 & & & \\
\hline Costs & $10000[\mathrm{zł}]$ & 9 & 9 & 3 & 3 \\
\hline Delivery time & 5 [weeks] & 9 & 9 & 9 & 9 \\
\hline Warranty & 12 [months] & 9 & & 9 & 9 \\
\hline \multirow{5}{*}{ Grade } & \begin{tabular}{l|l} 
& 1 \\
\cline { 2 - 2 }
\end{tabular} & & & t8 & \\
\hline & 2 & & t6 & t9 & $\mathrm{t} 10, \mathrm{t} 11$ \\
\hline & 3 & & $\mathrm{t} 4$ & t7 & $\mathrm{t} 12$ \\
\hline & 4 & $\mathrm{t} 1, \mathrm{t} 2, \mathrm{t} 3$ & t5 & & \\
\hline & 5 & & & & \\
\hline
\end{tabular}

Fig. 3. Grades of feeding device configuration items with the use of QFD method

Assessment of product components helps to choose the proper components variant or variant which needs to be redesigned. The presented approach is useful in the knowledge-base system supporting decisions in product configuration.

2.5. Range of change identification, assessment of time of consumption related to engineering documentation preparation and the manufacturing process of the redesigned product

Changes in a redesigned product are focused on product structure and adapting the manufacturing process to allow to, e.g.: fulfil new function, reduce the delivery time, reduce costs.

The range of change in product structure depends on, among others, the type of function introduced to the product. Product function could by classified into a category: e.g. enable assembly in particular workplace, are able to work in explosive environment, transmit torque. Changes on functions related to product assembly could be focused on, e.g. changing output shaft diameter. Changing the type of product structure takes time needed to prepare the engineering documentation. 
Time consumption is one of the most important criteria which contribute to offer attractiveness. Delivery time could be assessed based on time consumption of engineering documentation preparation and the manufacturing process.

Knowledge representation related to time consumption of engineering documentation preparation could use procedural knowledge or ANN. Procedures of time consumption assessment was presented in [4, 5]. The presented procedures use the dependence between time consumption of design task and complexity and novelty of the project. Application of ANN to assessment of time consumption of engineering documentation preparation was described in [6].

Assessing time consumption of the manufacturing process needs the process structure and parameters planning. It is important to join product features with time consumption of the manufacturing process. Time consumption of the manufacturing process could be assessed with the use of synthesis and analytical estimation (in this method the course of work is broken into appropriately adopted elements of work organisation methods), analytical estimation (the time required for the task is build up from synthetic data), time study (the time of manufacturing tasks is measured) or be based on the artificial intelligence method.

Time consumption is needed to scheduling tasks related to redesign product configuration.

\subsection{Scheduling tasks related to redesigned product configuration, confirmation of product configuration}

Scheduling the tasks concerned with the redesigned product configuration needs methods which are useful in modelling indeterminate project. Project scheduling taking into consideration risk causes tasks which could be performed with certain probability.

One of the popular stochastic methods of project scheduling is GERT (Graphical Evaluation and Review Technique). GERT joins some ideas of the PERT method, the signal flow graph and logic elements in a graph [7].

GERT respects resources, e.g. time or money and probability of the activity being planned. In the GERT methods the following steps could be distinguished: building stochastic network, collecting data concerned with transmittance, reduction of stochastic network, determining timing or costing and probability of the planned activity, interpretation of results.

GERT enabled modelling of additional project tasks which come from risk identification and analysis. Timing of the redesigned product is a result of project scheduling, which could by included in the offer presented to the customer. 


\section{An example of a knowledge-based system supporting toothed gear configuration}

The aim of application is supporting decision making in the field of geared motors configuration. This knowledge based system is dedicated to customer service. The meaning of intelligent product recommendation was mentioned by Stahl [8] who described main problems related to software supporting trade.

The range of the presented knowledge base is limited to toothed gears which are components of geared motors and automate only chosen steps of product configuration algorithms presented in point 2 .

The presented software used PC Shell from Sphinx software packet and Exel. KBS was built with the use of chosen products offered by producers of toothed gears. This knowledge base system applied a rule based approach, procedures for knowledge representation and ANN. The problems solved by this KBS include:

- selection of toothed gears work arrangement,

- selection of toothed gear work coefficients,

- selection of toothed gear variants,

- evaluation of toothed gears variants,

- time consumption estimation of chosen tasks.

Selection of toothed gears work arrangement is supported by graphical classifier, which uses: work arrangement with two variants: horizontal and vertical, as well as type of product structure which distinguishes helical and bevel-helical reducers (Fig. 4) (based on [9]).

The next step is focused on choosing the type of toothed gear reducers. For that purpose, the following data should be submitted (Fig. 4): number of working hours per day, number of switching per hour, temperature in the place where the working unit operates. 

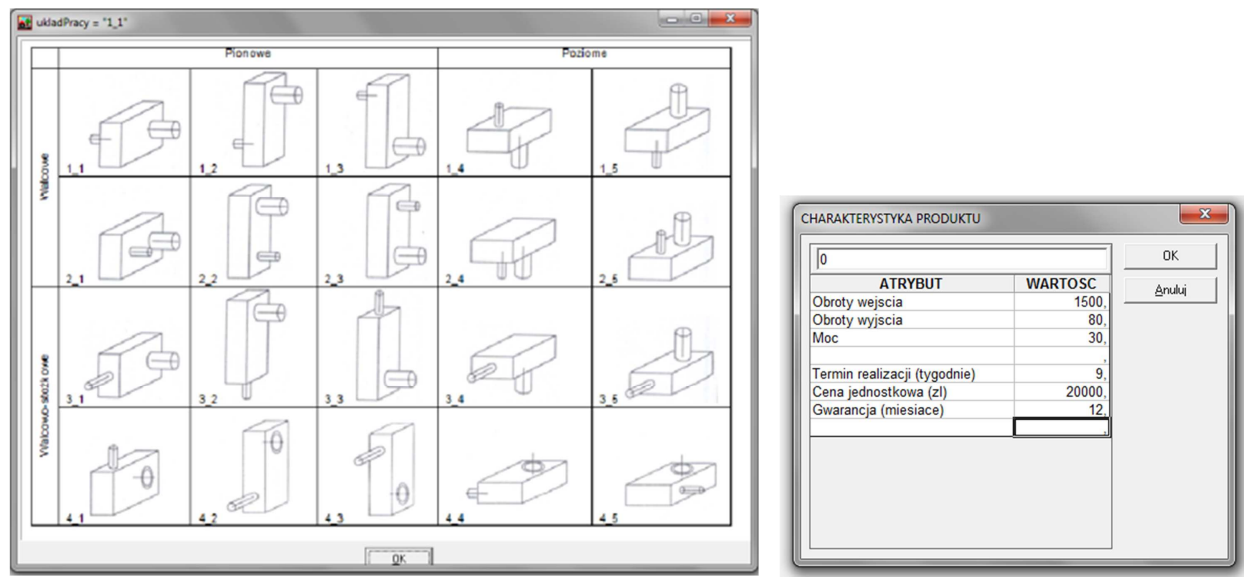

Fig. 4. Selection of toothed gear variants - data submission

The relations between customer requirements and product characteristics were presented with the use of the QFD method. An Excel sheet has been used as a tool for product evaluation according to the method presented in point 2 . On the bottom part of the matrix target values and products characteristic were put. On the right part of the matrix assessment grades for each evaluated product were presented (Fig. 5). 


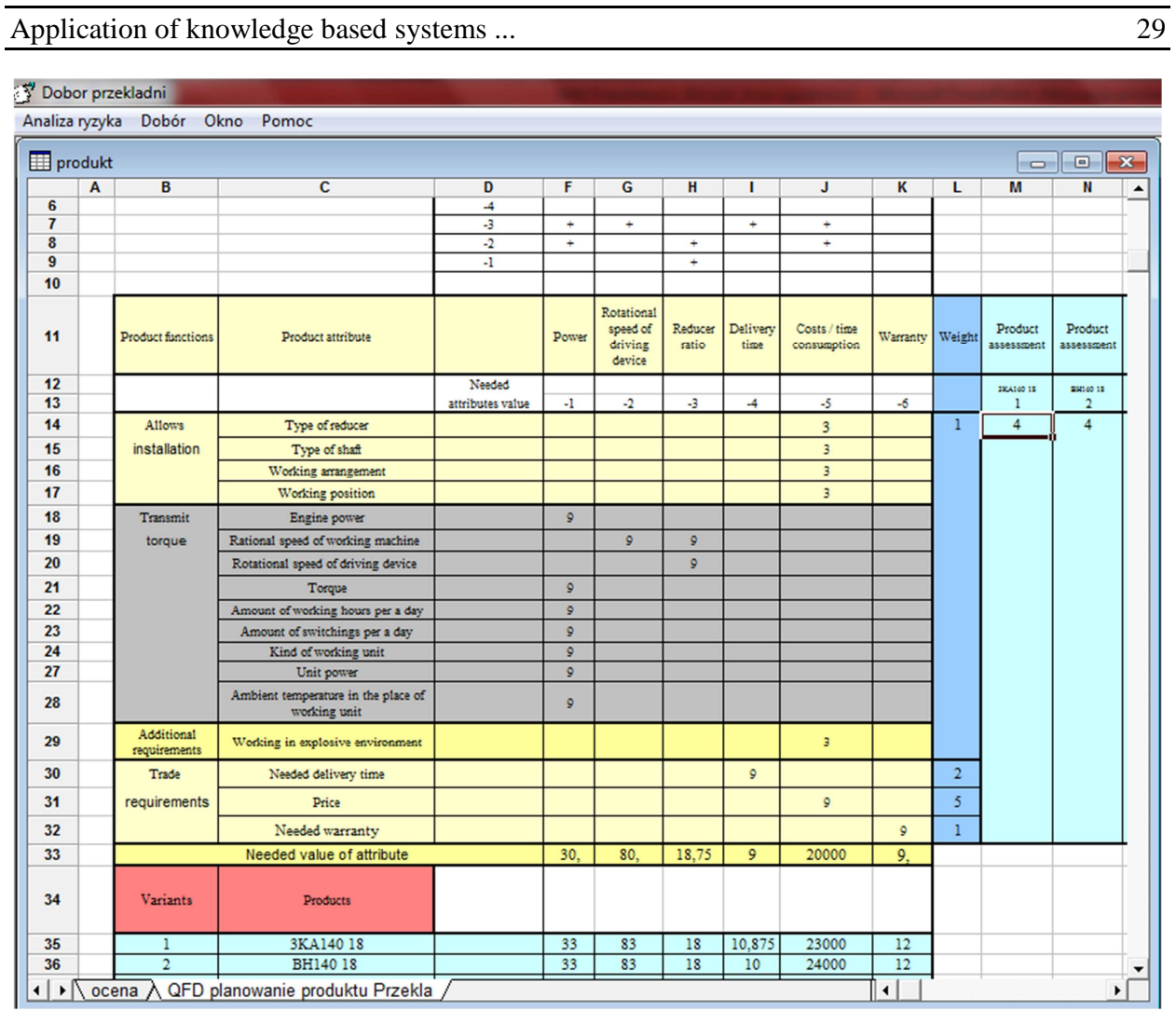

Fig. 5. Evaluation of toothed gear variants

\section{Conclusions}

The decision process regarding product configuration which is focused on compatibility between customer requirements and functional and physical product features can be supported with the use of knowledge based systems.

Methods of knowledge representation, such as procedures, rules, ANN and CBR are useful in the presented KBS. The presented approach uses advantages and avoids disadvantages of different methods of knowledge representation.

Integration of the knowledge related to customer requirements, product structure and the manufacturing process helps in assessing product characteristics in make-to-order product offer preparation. The proposed algorithm of product configuration uses the QFD method and performs the simplest searching, comparing, evaluating operations of different product variants as well as missing data estimation related to the production process of product redesign. 


\section{References}

[1] R. STRYCZEK: A hybrid approach for manufacturability analysis. Advances in Manufacturing Science and Technology, 35(2011)3, 55-70.

[2] J. POBOŻNIAK: Logic level of workpiece object database oriented on manufacturing features. Advances in Manufacturing Science and Technology, 36(2012)1, 19-31.

[3] PN-ISO 10007:2005 - Guidelines for configuration management.

[4] B. HLAVENKA: Rizeni a planovani technicke pripravy vyroby. SNTL, Praha 1983.

[5] K. PASTERNAK: Zarys zarządzania produkcją. PWE, Warszawa 2005.

[6] I. KUTSCHENREITER-PRASZKIEWICZ: Wykorzystanie sztucznych sieci neuronowych do prognozowania czasu projektowania przekładni zębatych w warunkach niepewności i ryzyka. Archiwum Technologii Maszyn i Automatyzacji, 27(2007)2, 113-120.

[7] K. KUKUŁA: Badania operacyjne w przykładach i zadaniach. PWN, Warszawa 2004.

[8] A. STAHL: Combining case-based and similarity-based product recommendation. Advances in Case-Based Reasoning, 4106(2006), 355-369.

[9] J. DREWNIAK: Wspomagane komputerowo projektowanie typoszeregów przekładni zębatych. Wydawnictwo Politechniki Łódzkiej, Bielsko-Biała 2000.

Received in October 2012 